\title{
Migration, wintering distribution and habitat use of an endangered tropical seabird, Barau's petrel Pterodroma baraui
}

\author{
Patrick Pinet $^{1, *}{ }^{\text {, Sébastien Jaquemet }}{ }^{1}$, David Pinaud ${ }^{2}$, Henri Weimerskirch ${ }^{2}$, \\ Richard A. Phillips ${ }^{3}$, Matthieu Le Corre ${ }^{1}$ \\ ${ }^{1}$ Université de La Réunion, Laboratoire ECOMAR, 15 avenue René Cassin, BP 7151, 97715 Saint Denis, Ile de La Réunion, \\ France \\ ${ }^{2}$ Centre d'Etudes Biologique de Chizé, CNRS, 79360 Villiers en Bois, France \\ ${ }^{3}$ British Antarctic Survey, Natural Environment Research Concil, High Cross, Madingley Road, Cambridge CB3 0ET, UK
}

\begin{abstract}
Gadfly petrels are strictly oceanic seabirds that range very far from their breeding grounds. Foraging movements outside the breeding season are poorly described. We used global location sensing (GLS) to describe the migration pathways and wintering habitats of Barau's petrels Pterodroma baraui, an endemic, endangered seabird of Réunion Island (western Indian Ocean). In 2 consecutive years, petrels migrated far eastward, up to $5000 \mathrm{~km}$ from their breeding colony, to the central and eastern Indian Ocean. Migration pathways, timing, and wintering areas varied little among individuals, and non-breeding areas were remarkably consistent between years. There was no sexual variation in migration patterns. Barau's petrels did not occur in the most productive areas of the Indian Ocean (Arabian Gulf and Somalia upwelling region) but instead foraged over warm oligotrophic and mesotrophic waters. Tracked birds consistently occurred in areas with relatively strong and consistent easterly winds, and avoided northern regions with weaker westerly winds. Our results indicate that Barau's petrels use an expansive wintering area between the western South Equatorial Current and the eastern Equatorial Counter Current, characterised by warm sea surface temperatures (SST) and low productivity. However, wind regimes in the Indian Ocean are strongly influenced by the Asian Monsoon; in this particular area, wind and currents may create a frontal system where prey are aggregated, increasing their accessibility for Barau's petrels. These results provide important baseline information for conservation, and are useful for the selection of potential marine reserves and the evaluation of effects of pollution or climate change on this highly threatened species.
\end{abstract}

KEY WORDS: Geolocation · Tropical seabird · Migration · Habitat use $\cdot$ Indian Ocean

\section{INTRODUCTION}

Understanding the patterns of spatial and temporal variations in animal abundance is a fundamental question in ecology (Tobin 2004). There have been numerous studies of the foraging ecology of seabirds during the breeding season, when birds regularly commute from their breeding grounds to their foraging areas (e.g. when they are 'central place foragers'). Far less is known about behaviour during the non-breeding period, mainly because of logistical and, until recently, technological limitations (Shealer 2002). However, this period, when birds no longer are central place foragers, is critical for recovering body condition in advance of the following breeding season (Barbraud \& Weimerskirch 2003).

Migration can be viewed as an adaptation to an overall range in which changes in habitat quality are 
spatially and temporally asynchronous, such that movement allows acquisition of resources as they become regionally available (Dingle \& Drake 2007). Thus, migration is more pronounced at higher latitudes where food supplies vary seasonally (Newton 2008). For example, in the Pacific, sooty shearwaters Puffinus griseus undertake a long, trans-equatorial migration, rapidly crossing warm, oligotrophic tropical waters to winter in productive temperate and subarctic areas (Shaffer et al. 2006). Recent studies have demonstrated similar, long trans-equatorial migrations for some species in the Atlantic Ocean, including Arctic terns Sterna paradisaea, Cory's shearwaters Calonectris diomedea, and Manx shearwaters Puffinus puffinus (González-Solís et al. 2007, Guilford et al. 2009, Egevang et al. 2010). With the exception of some Cory's shearwaters, these species winter in high-productivity areas of the south Atlantic.

Key questions therefore remain about the behaviour of seabirds that breed in tropical environments: Do they stay in tropical waters year-round, or do they migrate to predictable upwelling regions, or to productive areas elsewhere? Do they adapt their migrations to annual conditions, and does this strategy lead to high inter-annual variability? To our knowledge, the postbreeding migration of tropical seabirds has been investigated in detail in only one species, the wedgetailed shearwater Puffinus pacificus from Aride Island, Seychelles, in the western Indian Ocean (Catry et al. 2009). These shearwaters remained in tropical waters throughout the year, performing an eastward migration to the central Indian Ocean rather than targeting productive areas in adjacent regions such as the upwelling of Somalia or the Arabian Gulf. A preliminary tracking study conducted on just 2 magnificent frigatebirds Fregata magnificens from Grand Connétable Island off French Guiana and a single great frigatebird Fregata minor from Europa Island (Indian Ocean) indicates that these 2 tropical species perform a largescale (up to $1000 \mathrm{~km}$ ) migration after breeding, but, like the wedge-tailed shearwater, remain in tropical waters (Weimerskirch et al. 2006).

Gadfly petrels (genus Pterodroma) are medium-size seabirds (350 to $450 \mathrm{~g}$ ) that breed on tropical, subtropical, and subantarctic oceanic islands. They are exclusively pelagic species and range far and wide from their breeding grounds (see MacLeod et al. 2008), but their foraging movements outside the breeding season are unknown. Using miniaturized geolocators (also termed Global Location Sensor or GLS loggers), we studied the post-breeding migration of Barau's petrel Pterodroma baraui, a tropical seabird endemic to Réunion Island (western Indian Ocean), during 2 consecutive years. Past records based on ship surveys have shown segregation between breeding and non- breeding foraging areas (reviewed in Pinet et al. 2009). These studies indicated that Barau's petrel was clearly migratory, dispersing over a large area of open ocean. However, in the absence of tracking data, the nonbreeding distribution and details of individual movements of this species remained unknown. The goals of our study were to: (1) identify the main migratory pathways and wintering areas; (2) describe winter habitat occurrences, and; (3) investigate inter-annual variability in migration patterns.

\section{MATERIALS AND METHODS}

Study site and tracking data. Fieldwork was conducted at Réunion Island $\left(55.33^{\circ} \mathrm{E}, 21.07^{\circ} \mathrm{S}\right)$, in the western Indian Ocean, where between 6000 and 8500 pairs of Barau's petrel breed from September to April (Bretagnolle \& Attie 1991, Le Corre et al. 2002). Barau's petrels are threatened at their breeding colonies by introduced cats, which dramatically increase adult mortality (Le Corre 2008, Faulquier et al. 2009, Russell et al. 2009), and by light-induced mortality of fledglings (Le Corre et al. 2002). Threats at sea, including interactions with fisheries, remain unknown.

Twenty-three Mk14 geolocators (British Antarctic Survey) measuring $20 \times 8.5 \times 5.5 \mathrm{~mm}$ and weighing $1.5 \mathrm{~g}$ ( $0.4 \%$ of the mean adult mass: $380 \mathrm{~g}$ ) were deployed on Barau's petrels during 2 consecutive years; between February and March 2008 (end of the breeding season), 23 loggers were deployed on 11 breeders and 12 nonbreeders, and between November 2008 and March 2009, 12 loggers were deployed on 11 breeders and 1 non-breeder). Each logger was attached to a metal ring on the tarsus. The colony was visited during both daylight and darkness to increase the chances of recapturing birds. The loggers record light intensity and immersion in seawater. Light levels are measured every $60 \mathrm{~s}$, and the maximum value is logged at the end of each successive 10 min interval. Tracked birds were sexed using molecular methods (Fridolfsson \& Ellegren 1999) from blood collected from the tarsal vein.

Geolocation analysis. This paper focuses on the post-breeding migration (data from the breeding season will be analysed separately). For each track, we determined the departure and return dates using light and immersion data (no light during day time and/or no immersion indicates that the bird was in its burrow). The departure date was determined as the last day when the bird was in the burrow, confirmed by direct monitoring of attendance at the colony. The return date was defined as the first day the bird entered its burrow at the end of the winter. Bird locations between these dates were estimated using the 'TripEstimation' package (Sumner et al. 2009, R Development Core 
team 2008 [www.r-project.org], Bost et al. 2009 supplementary material, Thiebot \& Pinaud 2010). Raw location estimations calculated from light data were first constrained by a land mask, the known locations of start and end points (the colony), and spatial boundaries beyond which locations were unrealistic. Then a state-space model (Kalman filter) (Kalman 1960), including specific behavioural parameters and Markov chain Monte Carlo simulations ('TripEstimation' package) were used to improve the spatial likelihood of the tracks. Regarding the behavioural parameters, we used species characteristics to determine a log-normal distribution of mean speed over each $12 \mathrm{~h}$ period set at $30 \mathrm{~km} \mathrm{~h}^{-1}$ (P. Pinet unpubl. data), with a speed variance set at $15 \mathrm{~km} \mathrm{~h}^{-1}$, equal to half mean speed, as recommended by the authors of the 'TripEstimation' package. The most probable track was obtained, with 2 locations per day, namely one at sunrise and one at sunset. This method also allowed realistic estimation of location during equinox periods with lower confidence intervals (Thiebot \& Pinaud 2010). Previous studies using geolocators on seabirds reported average errors \pm SD of $186 \pm 114 \mathrm{~km}$ (Phillips et al. 2004) and $202 \pm 171$ $\mathrm{km}$ (Shaffer et al. 2005).

Analysis of migration patterns. For each bird, we divided the non-breeding period into 3 phases: the outward migration (OM), the wintering period (WP) and the return migration (RM). Outward and return migrations were easily characterised by more rapid, directed movements, whereas during the wintering period, movements showed greater sinuosity and lower travel speeds. For each bird and for the pooled dataset, we performed kernel analysis on locations along the predicted track using the 'adehabitat' (smoothing parameter $h$ of $1^{\circ}$ and $100 \times 100 \mathrm{~km}$ grid cells) in the statistical software R (www.r-project.org). We considered the 50 and $95 \%$ kernel density contours to represent the core areas of activity and the area of active use, respectively (Hamer et al. 2007, Catry et al. 2009). For each individual, the duration of the post-breeding migration was the time from colony departure to arrival at the first core wintering area (i.e. the $50 \%$ contour). Similarly, the return migration was the time between the last date in a core area and return to the colony. Differences in distribution between years and sexes were based on the proportional overlap of the 50 and $95 \%$ kernels (González-Solís et al. 2000, Hyrenbach et al. 2002).

Habitat use analysis. We compared environmental characteristics in the core region (within the $50 \%$ kernel contour) with those in peripheral areas (the region between the 50 and $95 \%$ contour, corresponding to the remainder of the area of active use). Given the inherent error in geolocation, we used a spatial resolution of $1^{\circ}$ for all environmental data. The oceanographic char- acteristics selected for comparison were based on the possible relevance to Barau's petrel foraging behaviour. Bathymetry (Bat) is a constant factor, whereas SST, chlorophyll a (chl a; a proxy of biological production in the upper layer of the ocean), and wind speed (Wind) are dynamic. We considered 4 different productivity regimes based on chl a values: oligotrophic (chl $a<0.1 \mathrm{mg} \mathrm{m}^{-3}$ ), mesotrophic ( $\mathrm{chl} a=0.1$ to $0.3 \mathrm{mg}$ $\mathrm{m}^{-3}$ ), eutrophic ( $\mathrm{chl} \mathrm{a}=0.3$ to $1 \mathrm{mg} \mathrm{m}^{-3}$ ), and enriched waters (chl a >1 $\mathrm{mg} \mathrm{m}^{-3}$ ) (Kahru \& Mitchell 2000). Bathymetric data were obtained from NOAA's ETOPO 1 min data set. We used monthly averages (downloaded from Bloomwatch database: http://coastwatch. pfel.noaa.gov) for all remotely sensed factors to investigate habitat characteristics and habitat selection. One-way ANOVAs, followed by post hoc Tukey tests, were used to compare oceanographic means (water depth, sea surface temperature [SST]), wind speed and chl a concentrations extracted for each kernel core) of areas used by Barau's petrels. Statistical analyses were performed with R software.

\section{RESULTS}

\section{Logger recovery}

Of 23 devices deployed in 2008, 16 (70\%) were retrieved during the first 4 mo of the following breeding season (September to December 2008). Of these 16, 12 (from 9 females and 3 males) were downloaded successfully. Eleven of 12 loggers deployed in 2009 were recovered (95\%; 9 males and 2 females), which all downloaded successfully. Post-breeding Barau's petrels were tracked for a mean $( \pm \mathrm{SD})$ of $169.3 \pm 16.5 \mathrm{~d}$ in 2008 , and $165.6 \pm 9.1 \mathrm{~d}$ in 2009, totalling 4188 and 3550 locations, respectively (Table 1). We did not find any obvious detrimental effects of the loggers; out of the 18 breeding birds equipped, only 1 bird failed during the early incubation stage in 2009.

\section{Migration schedule}

All tracked birds departed the colony in late March and reached their wintering area (individual 50\% density contours) ca. $22 \pm 13$ d later, in mid-April, where they remained for ca. $127 \mathrm{~d}$. Birds that initiated migration earlier took longer to reach their core area $\left(\mathrm{r}^{2}=\right.$ $0.62, \mathrm{p}<0.005)$. The westward return migration started synchronously between 20 and 25 August 2009 and lasted 14 to $20 \mathrm{~d}$; hence, most birds returned to the colony between 5 and 15 September. This pattern did not differ between sexes, and both breeders and nonbreeders had similar migration schedules. Although 


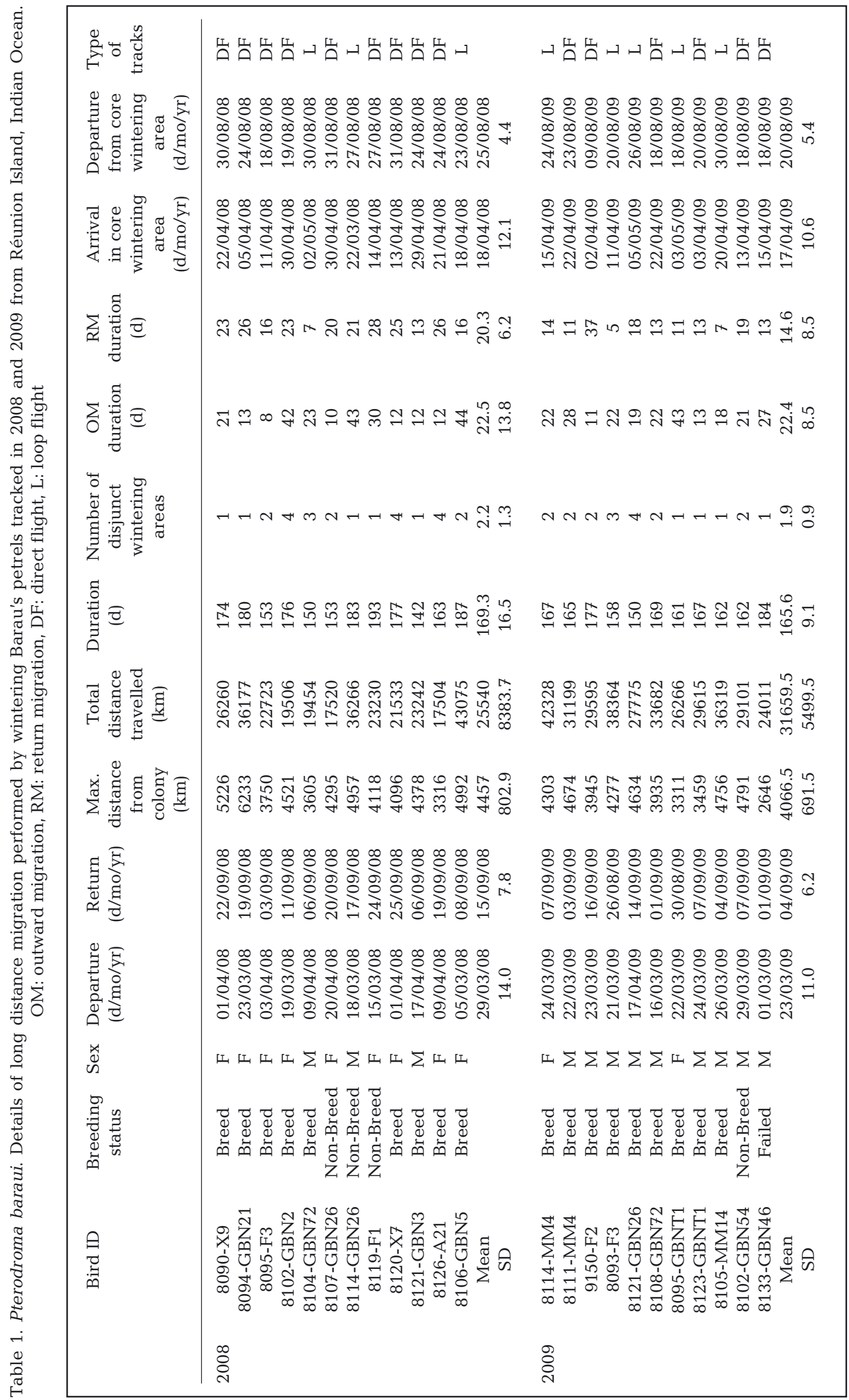


this general pattern was apparent in both years of the study, there were slight annual differences in timing: birds returned to their colony ca. 10 d earlier in 2009 compared with 2008 (4 September $\pm 6.2 \mathrm{~d}$ and 15 September $\pm 7.8 \mathrm{~d}$, respectively; $\left.t_{21}=3.75, \mathrm{p}<0.005\right)$. This difference could be sex-related, because males usually return to the colony earlier (P. Pinet pers. obs.), and the sex ratio of tracked birds in 2009 was strongly malebiased (vs. strongly female-biased in 2008).

\section{Migration routes and wintering areas}

After the breeding season, all tracked birds showed a consistent pattern of eastward migration to reach core wintering areas in the central and eastern tropical Indian Ocean (Fig. 1). Maximum distances from the colony ranged from 2646 to $6233 \mathrm{~km}$ (Table 1). The mean distance travelled per day for each bird during the outward and return migrations ranged from $110 \mathrm{~km}$ to $600 \mathrm{~km}$. On average, the minimum total distance covered during the whole wintering period (including movement within the core wintering area) was $28500 \mathrm{~km}$. Barau's petrels showed 2 types of migration flight: 15 birds travelled directly both from the colony to the wintering area and from the wintering area to the colony (direct commuting flight: DF), whereas 8 birds undertook a wide loop to the south before reaching their wintering area (loop flight: L) (see Table 1, Fig. 2). Although 5 birds performed their post-breeding migration between $25^{\circ} \mathrm{S}$ and $45^{\circ} \mathrm{S}$, migration flyways were mostly between $15^{\circ} \mathrm{S}$ and $25^{\circ} \mathrm{S}$ for the outward and return migrations (Fig. 1). There was no significant difference in the mean distance travelled in the $2 \mathrm{yr}$ of the

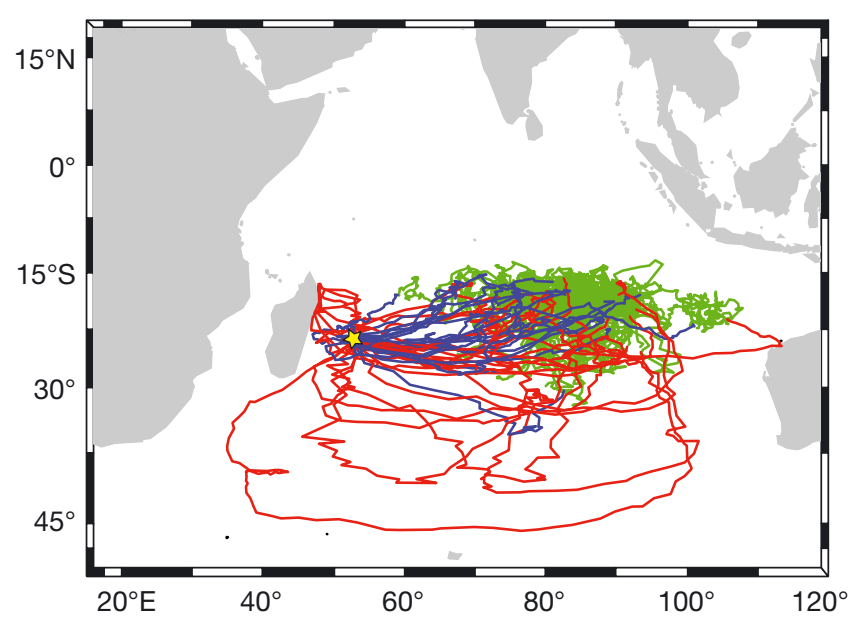

Fig. 1. Pterodroma baraui. Interpolated geolocation tracks of 23 Barau's petrels tracked from breeding colonies at Réunion Island from 2008 to 2009. Red line = outward migration (OM, March to April), green line = wintering period (WP, April to August), blue line = return migration $(\mathrm{RM}$, September). Yellow star $=$ breeding colony study, nor any apparent effect of sex or breeding status (breeders vs. non-breeders). The overall wintering distribution of the tracked birds was between 77 and $97^{\circ} \mathrm{E}$ in 2008, and 74 and $91^{\circ} \mathrm{E}$ in 2009 , around the Ninety East Ridge (Fig. 3). Birds travelled widely within core wintering areas, and daily travel distance was much shorter than during the outward and return migrations (Fig. 2). Wintering areas (50 and 95\% density contours) between years overlapped spatially, ranging from 50 to $81 \%$. The core area (50\% contour) in 2008 was 2 times larger than in $2009\left(2985743 \mathrm{~km}^{2}\right.$ and $1401733 \mathrm{~km}^{2}$, respectively). However, core areas between years overlapped by as much as $81 \%$, and sex-specific core areas overlapped by as much as $91 \%$.

\section{Marine habitats}

Oceanographic characteristics of wintering areas (50 and $95 \%$ density contours) of Barau's petrels are presented in Table 2. Wintering Barau's petrels consistently foraged over deep (2300 to $5500 \mathrm{~m})$, tropical $\left(22\right.$ to $28^{\circ} \mathrm{C}$ ), and oligotrophic (mean \pm SD: $0.09 \pm$ $0.03 \mathrm{mg} \mathrm{m}^{-3}$ of chl a) waters in both years of the study (Table 2). They were not found over shallow continental shelves (Fig. 4d) but used a restricted region of the open ocean between warm equatorial $\left(>28^{\circ} \mathrm{C}\right)$, and cool subtropical $\left(<22^{\circ} \mathrm{C}\right)$ waters (Fig. $\left.4 \mathrm{a}, \mathrm{b}\right)$. Although the core area was 2 times larger in 2008 than in 2009, no marked differences in environmental parameters were apparent. In both years, waters in core areas (50\% contours) had significantly greater chl a concentration and greater $\operatorname{SST}\left(F_{1,4982}=51.348, \mathrm{p}<0.0001\right.$ and $F_{1,4982}=$ $173.13, \mathrm{p}<0.0001$, respectively), than in the active area as a whole (between the 50 and $95 \%$ contour) (Fig. 4). Tracked birds consistently occurred in an environment with significantly stronger easterly winds $(9.48 \pm 0.96 \mathrm{~m}$ $\left.\mathrm{s}^{-1}\right)\left(F_{1,4982}=307.58, \mathrm{p}<0.0001\right.$, followed by post hoc Tukey tests) (Fig. 4c) and avoided regions of slow westerlies (Fig. 5). The extent of the region with strong winds was greater in 2008 than 2009 (Fig. 5), which could explain the reduction in distribution from one year to the next.

\section{DISCUSSION}

The distribution of Barau's petrels at sea was virtually unknown prior to this study; hence, this is the first study to describe in detail the migration and wintering areas of this endangered gadfly petrel. Indeed, to our knowledge, it is only the second study using geolocators to investigate the migration behaviour of a tropical seabird, and the first to do so in multiple years (cf. Catry et al. 2009). 

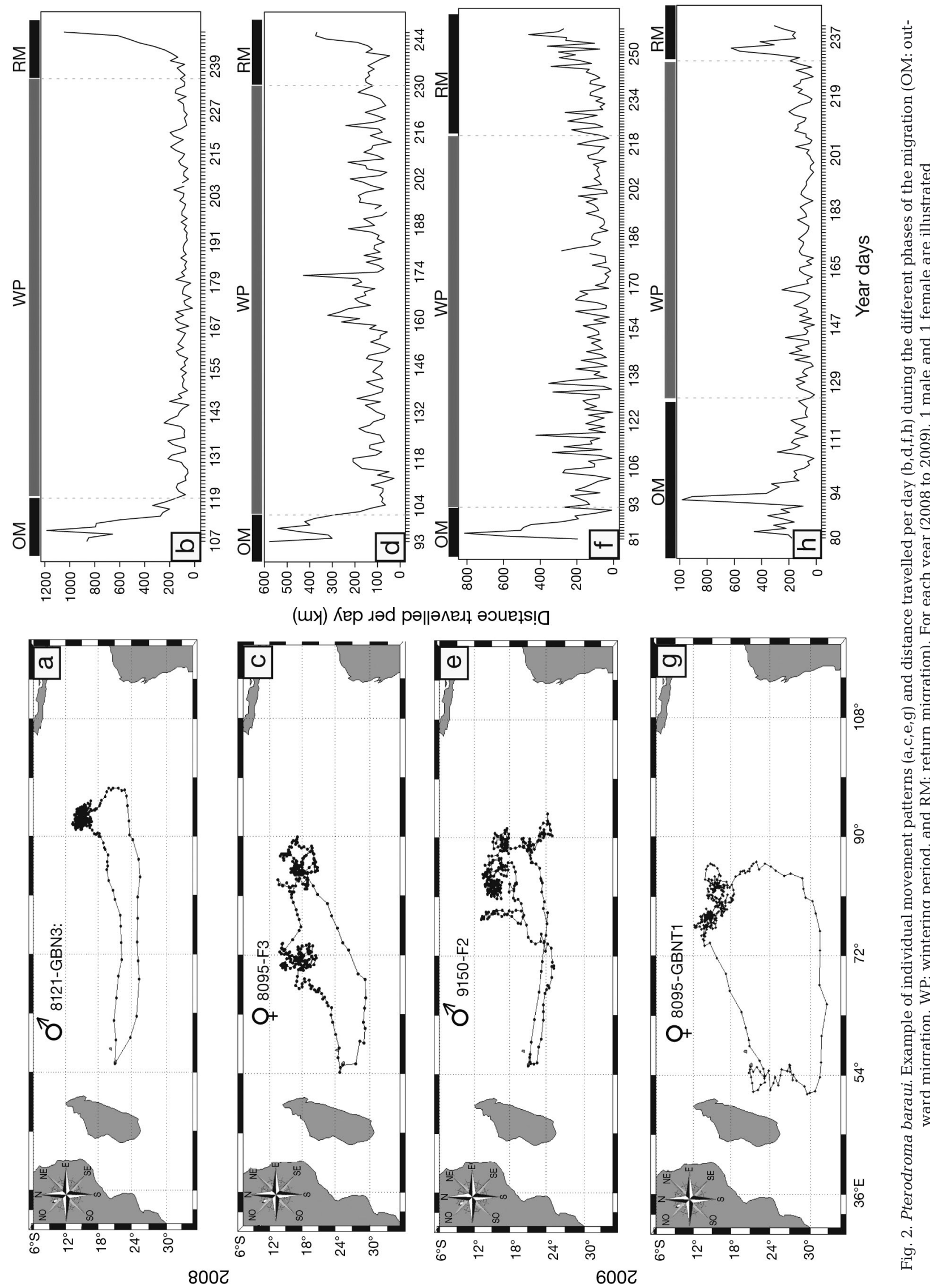

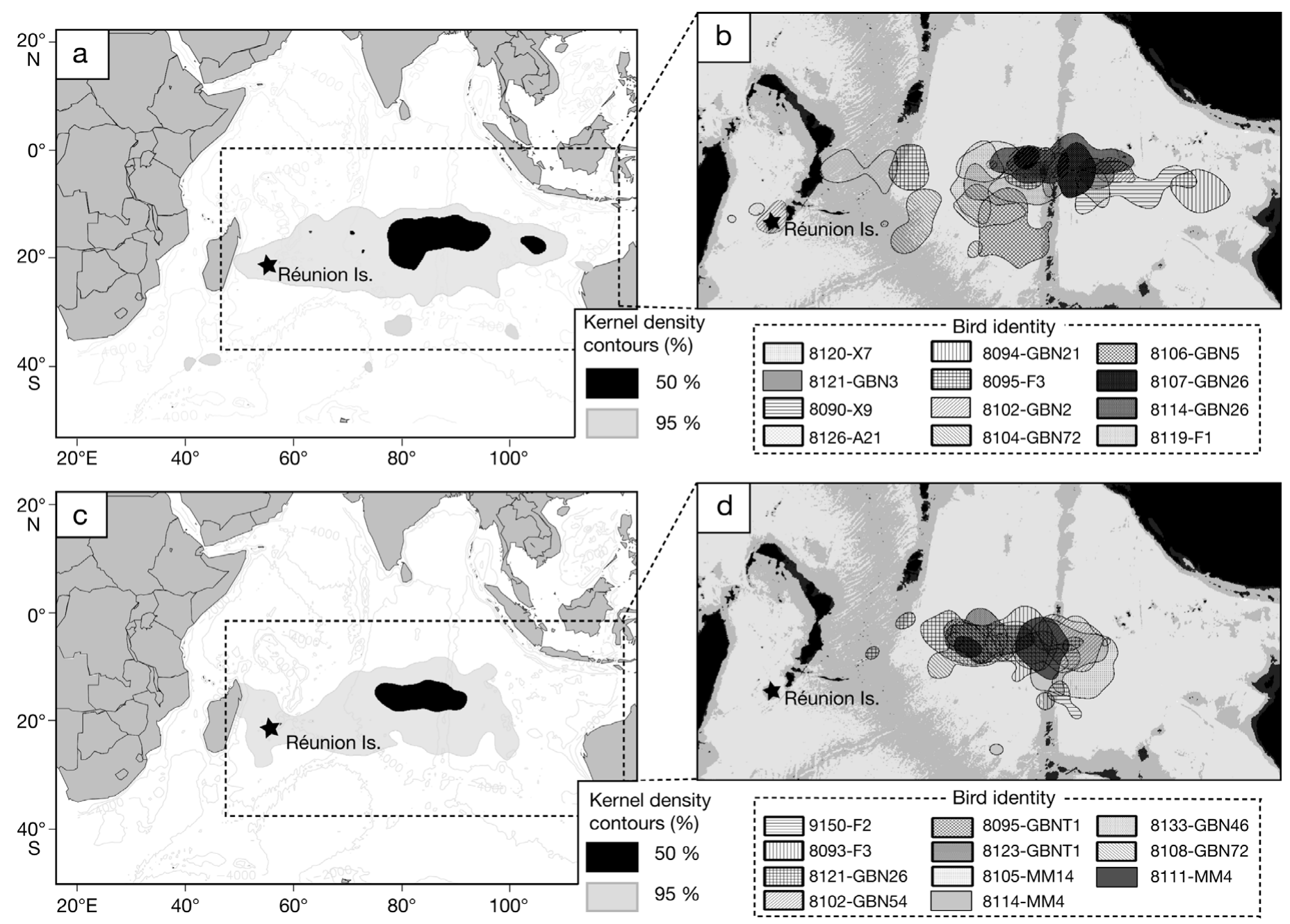

Fig. 3. Pterodroma baraui. Distributions of Barau's petrels around Réunion Island based on kernel analysis. (a) 50 and $95 \%$ density contours from pooled data in 2008, (b) $50 \%$ contours of each individual in 2008, (c) 50 and $95 \%$ density contours from pooled data in 2009 , and (d) $50 \%$ contours of each individual in 2009

Table 2. Mean, SD and range (in brackets) of water depth, sea surface temperature (SST), chlorophyll a (chl a) concentration and wind speed (Wind) within the wintering distributions of Barau's petrels in 2008 and 2009. Data are presented for the core area ( $50 \%$ kernel density) and for the area of active use (95\% kernel density)

\begin{tabular}{|ccccccc|}
\hline Year & $\begin{array}{c}\text { Kernel } \\
\text { density (\%) }\end{array}$ & \multicolumn{1}{c}{ Depth (m) } & \multicolumn{1}{c|}{ SST $\left({ }^{\circ} \mathrm{C}\right)$} & Chl $a\left(\mathrm{mg} \mathrm{m}^{-3}\right)$ & Wind $\left(\mathrm{m} \mathrm{s}^{-1}\right)$ \\
\hline 2008 & 50 & $4828 \pm 679(5780-2318)$ & $26.20 \pm 1.267(22.45-28.40)$ & $0.09 \pm 0.03(0.03-0.21)$ & $9.46 \pm 1.01(6.16-11.60)$ \\
& 95 & $4415 \pm 970(6113-800)$ & $25.25 \pm 2.03(19.41-28.88)$ & $0.08 \pm 0.03(0.03-0.34)$ & $8.66 \pm 1.26(4.61-11.60)$ \\
2009 & 50 & $4656 \pm 797(5440-2317)$ & $26.25 \pm 1.26(23.57-28.55)$ & $0.08 \pm 0.03(0.04-0.20)$ & $9.50 \pm 0.83(7.49-11.25)$ \\
& 95 & $4410 \pm 814(6025-1649)$ & $25.45 \pm 2.14(19.85-29.99)$ & $0.07 \pm 0.03(0.03-0.53)$ & $8.61 \pm 1.14(4.06-11.25)$ \\
\hline
\end{tabular}

\section{Migration timing, routes, and wintering areas}

All birds (both breeders and non-breeders) started their post-breeding migration synchronously at the end of the summer (late March) in both years, and returned to the nesting grounds in September. Interestingly, the mean return dates coincided with the full moon in both years of the study (2008: 15 September for both returns dates and full moon; 2009: 4 and 5 September, respectively), suggesting that the birds use this cue to synchronise their activity. The effect of moon cycle on attendance and various other aspects of behaviour of small burrowing seabirds at colonies has been considered previously in the context of antipredator behaviour (Imber 1975, Watanuki 1986, Le Corre et al. 2002). However, our results strongly sug- 


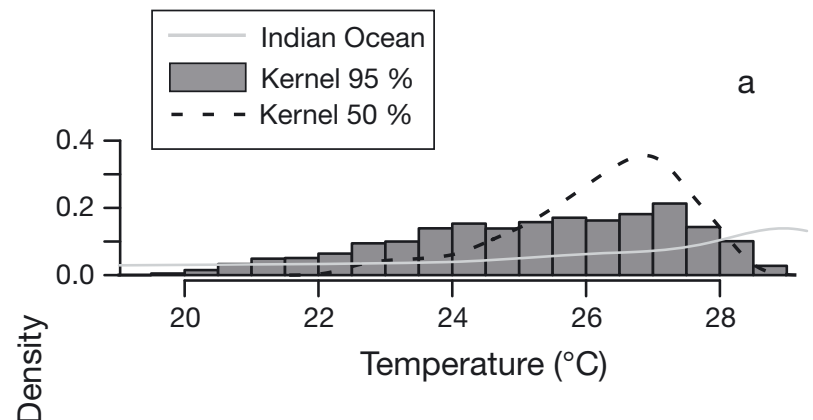

C

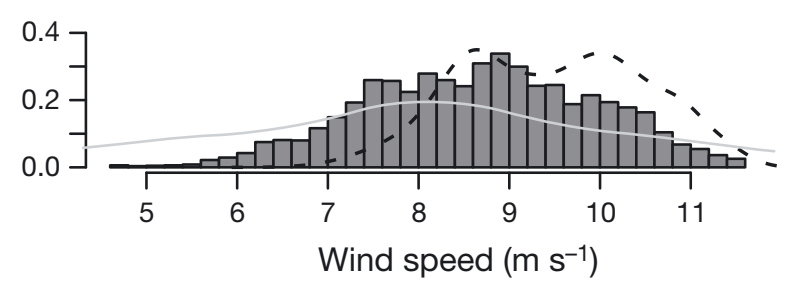

b

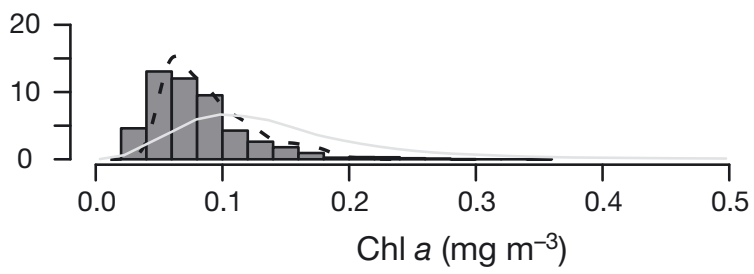

d

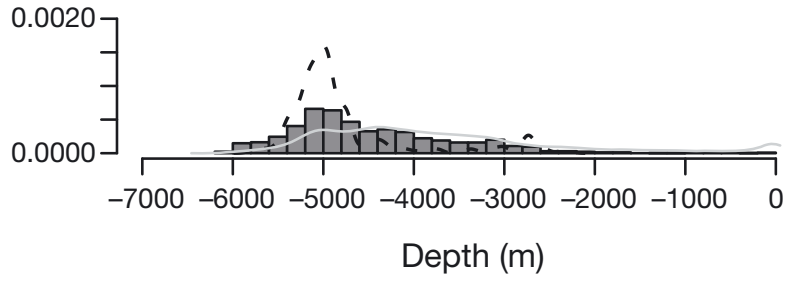

Fig. 4. Relative frequencies (e.g. density) of (a) sea surface temperature (SST), (b) chlorophyll a (chl a), (c) wind speed, and (d) depth available in the Indian Ocean $\left(20^{\circ} \mathrm{N}\right.$ to $50^{\circ} \mathrm{S}, 20^{\circ} \mathrm{E}$ to $120^{\circ} \mathrm{E}$ ) and present in the active area (bounded by the $95 \%$ density contour) and the core area (bounded by the $50 \%$ density contour) used by Barau's petrels in 2008 and 2009

gest that moon calendar also influences timing of migration, such that the first return of Barau's petrels to the colony always takes place during bright, moonlit nights.

Contrary to inferences from boat surveys (reviewed in Pinet et al. 2009), adult Barau's petrels (both breeders and non-breeders from the preceding summer) do not disperse widely over the whole Indian Ocean during the winter, but instead show a consistent eastward migration to a specific area of the central and eastern Indian Ocean. All tracked birds in this study flew to this area, travelling on average $4250 \mathrm{~km}$ in $22 \mathrm{~d}$ (see Table 1). Once in these core wintering areas, distance travelled per day was much lower (see Fig. 2). This change in flight characteristics is typical of birds arriving at foraging grounds (Weimerskirch et al. 1997, Pinaud \& Weimerskirch 2005, 2007).

Barau's petrels did not select the more productive areas of the Indian Ocean (Arabian Gulf and upwelling of Somalia) but foraged over oligotrophic and mesotrophic waters far from the coast. Past at-sea sightings suggested a northward distribution in the southern Arabian Sea (Van den Berg et al. 1991), between the Maldives and Sumatra (van Marle \& Voous 1988, Van den Berg et al. 1991), and in the Cocos-Keeling Island region (Chapman \& Cheshire 1987). In contrast, none of our tracked birds migrated north of $10^{\circ} \mathrm{S}$, suggesting that at least by the age of attending colonies (as breeders or non-breeders), adults do not migrate that far north. Further tracking studies of adults and juveniles in the same year would be needed to confirm this hypothesis.

\section{Marine habitats used}

Overall, chl a concentrations are low in the western and central Indian Ocean, especially in comparison with equatorial regions of the Pacific and Atlantic Oceans (Tomczak \& Godfrey 2003). The strongest upwellings in the Indian Ocean occur when the southeast monsoon produces strong Ekman transport away from the coasts of Somalia, Arabia, India and Sri Lanka (Tomczak \& Godfrey 2003). Barau's petrels did not use these areas, despite the characteristically high primary productivity found there and a travel distance from Réunion Island $(<4000 \mathrm{~km})$ comparable with that to the wintering areas identified in our study.

Our results therefore indicate that Barau's petrels target wintering regions with specific oceanographic or biological attributes that differ from more coastal upwelling, including the area south of $10^{\circ} \mathrm{S}$ between the eastward Equatorial Counter Current and the westward South Equatorial Current. This area is characterized by a combination of strong winds and mesotrophic waters. South of $10^{\circ} \mathrm{S}$, the southeast trade winds persist throughout the year and have their seasonal maximum and most northerly extent during the southern winter (Schott \& McCreary 2001). It is now fairly well established that the periods of elevated biological activity result from the semi-annual wind reversals associated with the monsoon system (Wiggert et al. 2005, 2006). Over the northern Indian Ocean (north of $10^{\circ} \mathrm{S}$ ), winds generally blow from the southwest during the summer monsoon and from the northeast during the winter monsoon. These seasonally reversing 

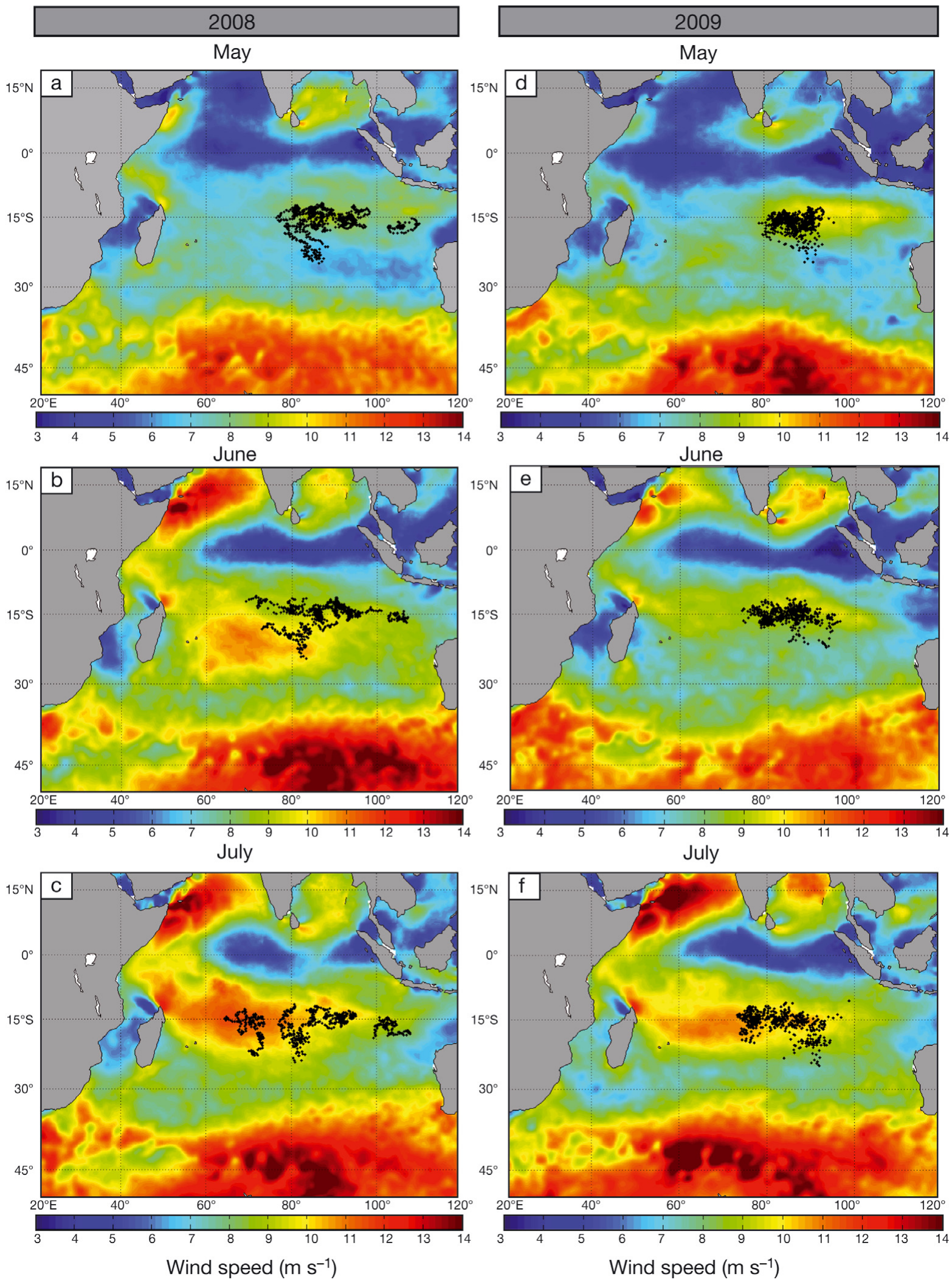

Fig. 5. Pterodroma baraui. Wintering locations (black $\bullet$ ) in 3 different months overlaid on monthly average wind speed in the Indian Ocean over the same periods: (a) May 2008, (b) June 2008, (c) July 2008, (e) May 2009, (f) June 2009, and (g) July 2009 
winds force a seasonally reversing circulation in the upper ocean (Schott \& McCreary 2001, Shankar et al. 2002). Monsoon winds also cause vertical mixing and produce coastal and open ocean upwelling and downwelling (Lee et al. 2000, Schott \& McCreary 2001). This complex system leads to pronounced basin-wide spatio-temporal variability in the physical factors affecting productivity, i.e. the surface delivery of limiting nutrients and the mixed-layer depth (Nair et al. 1989, Lévy et al. 2007). This drastic variation in wind and currents north of $10^{\circ} \mathrm{S}$ may create a frontal system at the southern limit of which productivity and prey are concentrated. The regional analysis of phytoplankton blooms published by Levy et al. 2007 showed a wellmarked seasonal bloom occurring during austral winter in the central Indian Ocean (see Fig. 3e in Levy et al 2007). Interestingly, the wintering area of Barau's petrels matches very well with this bloom, suggesting that birds take advantage of these seasonal and predictable enrichments.

There is increasing evidence that the long-distance movements of migratory seabirds are heavily influenced by seasonality in wind strength and direction (Felicísimo et al. 2008, Egevang et al. 2010). Our results show that Barau's petrels favour areas with relatively strong winds during the non-breeding period. Based on the hypothesis of wind-driven movement, calm weather or strong head winds act as a barrier that can affect trans-oceanic paths (Felicísimo et al. 2008). Hence, even if the northern Indian Ocean is more productive, we hypothesize that the unfavourable wind regime (direction and speed) north of $10^{\circ} \mathrm{S}$ would make these waters unavailable for wintering Barau's petrels. They may also avoid the Somalian and Arabian coasts because productive upwellings usually concentrate high densities of other foraging seabirds, hence leading to potentially greater inter-specific competition for resources (Ballance et al. 1997).

There is therefore a clear geographical segregation between wedge-tailed shearwaters from Aride in the Seychelles and Barau's petrels, which are found further south, between $15^{\circ} \mathrm{S}$ and $30^{\circ} \mathrm{S}$. The wintering areas of wedge-tailed shearwaters in the Indian Ocean correspond closely to the distribution of catches of yellowfin tuna Thunnus albacores and skipjack tuna Katsuwonus pelamis by fisheries and were mostly in waters between $5^{\circ} \mathrm{N}$ and $10^{\circ} \mathrm{S}$, which are under the influence of the Equatorial Counter Current (Catry et al. 2009). Previous studies suggest a number of mechanisms that may reduce the level of inter-specific competition for resources during the breeding season, including spatial, dietary, and behavioural segregation at sea (Hyrenbach et al. 2002, Waugh \& Weimerskirch 2003, Phillips et al. 2005a). Recent tracking data suggest, similarly, that the moderate to high degree of spatio-temporal isolation between congeners and conspecifics reduces competition during the non-breeding period (Croxall et al. 2005, Phillips et al. 2005b), which may be the reason for the lack of overlap between Barau's petrels and wedge-tailed shearwaters.

\section{Individual and annual variation}

Although the sex bias in our samples of tracked birds changed in the $2 \mathrm{yr}$ of our study, we found no suggestion of sexual segregation in wintering areas of Barau's petrels. This may indicate that males and females do not compete for food because resources are not strongly limiting in the wintering area, or because they have distinct diet preferences. There is currently no evidence for the latter; preliminary results from stable isotope analysis of feathers grown during the winter by Barau's petrels revealed no measurable sexual differences in trophic level (J. Kojadinovic unpubl. data). This conforms with results from a recent study of a suite of non-breeding procellariids, showing no apparent trophic segregation between sexes in smaller species that exhibit limited or no sexual size dimorphism (Phillips et al. 2009). Furthermore, Kojadinovic et al. (2008) suggested that the absence of large shifts in feeding behaviours of Barau's petrels from one season to another potentially indicated the use of the same preys during both breeding and non-breeding seasons, but further data on diet throughout the year are still needed to confirm this interpretation.

Routes and timing of migration of Barau's petrels varied little between individuals, but wintering areas were remarkably consistent from year to year. Interestingly, 8 of 23 birds performed loop flights farther south, where westerly winds were stronger. Wind strength and direction are known to be important factors affecting the overall movements that ultimately delineate the distribution of petrels at sea (Adams \& Flora 2009). For Barau's petrels, certain atmospheric conditions (e.g. anticyclones) could trigger migration towards the east.

There was a high overlap in wintering areas used in both years (Fig. 3). This indicates that Barau's petrels consistently select specific wintering grounds in tropical waters, despite these habitats generally being regarded as low-productivity and low-variability areas (see Longhurst \& Pauly 1987). Adams \& Flora (2009) showed that winds associated with slower moving (anticyclonic) and faster propagating (cyclonic) cells are an important influence on the at-sea distribution and long-range trajectories of procellariiform seabirds. In the Indian Ocean, productivity is known to be poor, unpredictable, and patchily distributed (Longhurst \& Pauly 1987). On the other hand, large-scale wind patterns are highly predictable and seasonal (Lévy et al. 
2007, Resplandy et al. 2009). Given the strong overlap between the wintering areas of Barau's petrels and strong winds (Fig. 5), we hypothesise that wind regime plays a major role in determining migration pathways and in the selection of wintering areas in this species (see also Liechti 2006).

\section{Implication for conservation}

As already mentioned, the Barau's petrel is an endangered seabird (IUCN 2010) endemic to Réunion Island. The main threats identified so far are all landbased: predation of adults and chicks by feral cats at colonies (Faulquier et al. 2009) and massive fledgling mortality induced by urban light attraction (Le Corre et al. 2002). Population modelling has shown that these threats, especially those reducing adult survival (like cat predation), may drive the species to extinction (Le Corre 2008, Russell et al. 2009, Dumont et al. 2010). Thus, a conservation plan is currently being implemented to save the species from extinction (Salamolard 2007). One of the issues pointed out by this conservation plan was the major knowledge gap on the marine stage of the Barau's petrel, preventing any assessment of the threats of this species when at sea.

The results presented here very clearly fill this gap. More specifically, we have shown here that the bulk of the Barau's petrel population winter consistently in a well defined area of the central and eastern Indian Ocean. Although we do not know yet if the species is affected by human activities in this wintering area, identifying the 'wintering hotspot' is of major importance if the goal is to protect the species during its complete vital cycle. Further studies focused on this specific area should be conducted to better understand why Barau's petrels consistently select this region, whether other species also do so, and to identify potential threats.

Acknowledgements. This study is a production of the 'Seabird team' of the ECOMAR laboratory. It was supported by the French Ministry of Overseas Territories (program BARGOS EDUC), the Fédération Française de Recherche sur la Biodiversité (FRB program AOOI-07-011), the Parc National des Hauts de La Réunion and by the Pew Environment Group (Pew Fellow Grant of MLC in Marine Conservation). P.P. also benefited from a PhD grant from the Regional Council of Réunion Island and the European Social Fund. The authors thank all the field workers involved in the project since 2008 (A. Pierre, M. Riethmuller, F. Jan, E. Buffard, P. Souharce, M. Salamolard, C. Caumes, P.Y. Besson, A. Valery, J. Russell, G. Potin, C. de Laburthe, and the many volunteers who participated over the years). We also thank the Brigade de La Nature of the Indian Ocean and the Peloton de Gendarmerie de Haute Montagne of Cilaos for their useful field assistance and their motivation. We thank the Parc National of Réunion Island for their assistance in the monitoring effort and in logistics. We thank L. Humeau (Laboratory PVBMT, Université de la Réu- nion) for the molecular sexing analysis. We also thank the SEOR (Société d'Etudes Ornithologiques de La Réunion) and all the volunteers for their help and their implication for the Barau's petrel conservation. This research represents a contribution to the British Antarctic Survey Ecosystems Programme. We also thank 3 referees for very helpful comments and corrections on the manuscript.

\section{LITERATURE CITED}

Adams J, Flora S (2009) Correlating seabird movements with ocean winds: linking satellite telemetry with ocean scatterometry. Mar Biol 15:915-929

Ballance LTR, Pitman RL, Reilly SB (1997) Seabird community structure along a productivity gradient: importance of competition and energetic constraint. Ecology 78: 1502-1518

Barbraud C, Weimerskirch H (2003) Climate and density shape population dynamics of a marine top predator. Proc Biol Sci 270:2111-2116

Bost CA, Thiebot JB, Pinaud D, Cherel Y, Trathan PN (2009) Where do penguins go during the inter-breeding period? Using geolocation to track the winter dispersion of the macaroni penguin. Biol Lett 5:473-476

> Bretagnolle V, Attie C (1991) Status of Barau's petrel (Pterodroma baraui): colony sites, breeding population and taxonomic affinities. Colon Waterbirds 14:25-33

Catry T, Ramos JA, Le Corre M, Phillips RA (2009) Movements, at-sea distribution and behaviour of a tropical pelagic seabird: the wedge-tailed shearwater in the western Indian Ocean. Mar Ecol Prog Ser 391:231-242

Chapman S, Cheshire N (1987) Notes on seabird reports received 1986. Sea Swallow 36:32-46

Croxall JP, Silk JRD, Phillips RA, Afanasyev V, Briggs DR (2005) Global circumnavigations: tracking year-round ranges of nonbreeding albatrosses. Science 307:249-250

- Dingle V, Drake VA (2007) What is migration? Bioscience 57: 113-121

> Dumont Y, Russell JC, Lecomte V, Le Corre M (2010) Conservation of endangered endemic seabirds within a multipredator context: the Barau's petrel in Réunion Island. Nat Resour Model 23:381-446

Egevang C, Stenhouse IJ, Phillips RA, Petersen A, Fox JW, Silk JRD (2010) Tracking of Arctic terns Sterna paradisaea reveals longest animal migration. Proc Natl Acad Sci USA 107:2078-2081

> Faulquier L, Fontaine R, Vidal E, Salamolard M, Le Corre M (2009) Feral cats Felis catus threaten endangered endemic Barau's Petrel Pterodroma baraui at Réunion Island (western Indian Ocean). Waterbirds 32:330-336

Felicísimo ÁM, Muñoz J, González-Solís J (2008) Ocean surface winds drive dynamics of transoceanic aerial movements. PLoS ONE 3:e2928

Fridolfsson A, Ellegren H (1999) A simple and universal method for molecular sexing of non-ratite birds. J Avian Biol 30:116-121

> González-Solís J, Croxall JP, Wood AG (2000) Foraging partitioning between giant petrels Macronectes spp. and its relationship with breeding population changes at Bird Island, South Georgia. Mar Ecol Prog Ser 204:279-288

> González-Solís J, Croxall JP, Oro D, Ruiz X (2007) Transequatorial migration and mixing in the wintering areas of a pelagic seabird. Front Ecol Environ 5:297-301

> Guilford T, Meade J, Willis J, Phillips RA and others (2009) Migration and stopover in a small pelagic seabird, the Manx shearwater Puffinus puffinus: insights from machine learning. Proc Biol Sci 276:1215-1223 
Hamer KC, Humphreys EM, Garthe S, Hennicke J and others (2007) Annual variation in diets, feeding locations and foraging behaviour of gannets in the North Sea: flexibility, consistency and constraint. Mar Ecol Prog Ser 338: 295-305

- Hyrenbach KD, Fernãndez P, Anderson DJ (2002) Oceanographic habitats of two sympatric North Pacific albatrosses during the breeding seasons. Mar Ecol Prog Ser 233: 283-301

Imber MJ (1975) Behaviour of petrels in relation to the moon and artificial lights. Notornis 22:302-306

IUCN (2010) IUCN red list of threatened species. Version 2010.4., available at www.iucnredlist.org

Kahru M, Mitchell B (2000) Influence of the 1997-98 El Niño on the surface chlorophyll in the California Current. Geophys Res Lett 27:2937-2940

Kalman R (1960) A new approach to linear filtering and prediction problems. Trans ASME J Basic Eng 82:35-45

Kojadinovic J, Menard F, Bustamante P, Cosson R, Le Corre M (2008) Trophic ecology of marine birds and pelagic fishes from Reunion Island as determined by stable isotope analysis. Mar Ecol Prog Ser 361:239-251

Le Corre (2008) Cats, rats and seabirds. Nature 451:134-135

Le Corre M, Ollivier A, Ribes S, Jouventin P (2002) Lightinduced mortality of petrels: a 4-year study from Réunion Island (Indian Ocean). Biol Conserv 105:93-102

Lee CM, Jones BH, Brink KH, Fischer AS (2000) The upper ocean response to monsoonal forcing in the Arabian Sea: seasonal and spatial variability. Deep-Sea Res II 47: $1177-1226$

Lévy M, Shankar D, André JM, Shenoi SSC, Durand F, de Boyer Montégut C (2007) Basin-wide seasonal evolution of the Indian Ocean's phytoplankton blooms. J Geophys Res 112:C12014 doi:10.1029/2007JC004090

- Liechti F (2006) Birds: blowin' by the wind? J Ornithol 147: $202-211$

Longhurst AR, Pauly D (1987) Ecology of tropical oceans. Academic Press, San Diego, CA

MacLeod CJ, Adams J, Lyver P (2008) Temporal and spatial variation in Grey-faced petrel Pterodroma macroptera gouldi distribution at sea during the breeding season. Pap Proc R Soc Tasman 142:73-88

Nair R, Ittekkot V, Manganini S, Ramaswamy V and others (1989) Increased particle flux to the deep ocean related to monsoons. Nature 338:749-751

Newton I (2008) The migration ecology of birds. Academic Press, London

- Phillips RA, Silk JRD, Croxall JP, Afanasyev V, Briggs DR (2004) Accuracy of geolocation estimates for flying seabirds. Mar Ecol Prog Ser 266:265-272

Phillips RA, Silk JRD, Croxall JP (2005a) Foraging and provisioning strategies of the light-mantled sooty albatross at South Georgia: competition and coexistence with sympatric pelagic predators. Mar Ecol Prog Ser 285:259-270

Phillips RA, Silk JRD, Croxall JP, Afanasyev V, Bennett VJ (2005b) Summer distribution and migration of nonbreeding albatrosses: individual consistencies and implications for conservation. Ecology 86:2386-2396

Phillips RA, Bearhop S, McGill RAR, Dawson DA (2009) Stable isotopes reveal individual variation in migration strategies and habitat preferences in a suite of seabirds during the nonbreeding period. Oecologia 160:795-806

Pinaud D, Weimerskirch H (2005) Scale-dependent habitat use in a long-ranging central place predator. J Anim Ecol 74:852-863

Pinaud D, Weimerskirch H (2007) At-sea distribution and scale-dependent foraging behaviour of petrels and albatrosses: a comparative study. J Anim Ecol 76:9-19

Pinet P, Salamolard M, Probst JM, Russell JC (2009) Barau's petrel Pterodroma baraui: history, biology and conservation

Editorial responsibility: Hans Heinrich Janssen,

Oldendorf/Luhe, Germany of an endangered endemic petrel. Mar Ornithol 37: 107-113

Resplandy L, Vialard J, Lévy M, Aumont O, Dandonneau Y (2009) Seasonal and intraseasonal biogeochemical variability in the thermocline ridge of the southern tropical Indian Ocean. J Geophys Res 114:C07024 doi:10.1029/ 2008JC005246

Russell JC, Lecomte V, Dumont Y, Le Corre M (2009) Intraguild predation and mesopredator release effect on longlived prey. Ecol Modell 220:1098-1104

Salamolard M (2007). Plan de conservation du Pétrel de Barau (Pterodroma baraui). Rapport ECOMAR. Réunion University and Société d'Etudes Ornithologiques de la Réunion, Réunion

Schott FA, McCreary JP (2001) The monsoon circulation of the Indian Ocean. Prog Oceanogr 51:1-123

Shaffer S, Tremblay Y, Awkerman J, Henry R and others (2005) Comparison of light-and SST-based geolocation with satellite telemetry in free-ranging albatrosses. Mar Biol 147:833-843

Shaffer SA, Tremblay Y, Weimerskirch H, Scott D and others (2006) Migratory shearwaters integrate oceanic resources across the Pacific Ocean in an endless summer. Proc Natl Acad Sci USA 103:12799-12802

> Shankar D, Vinayachandran PN, Unnikrishnan AS (2002) The monsoon currents in the north Indian Ocean. Prog Oceanogr 52:63-120

Shealer DA (2002) Foraging behavior and food of seabirds. In: Schreiber EA and Burger J (eds) Biology of marine birds. CRC Press, Boca Raton, FL, p 137-177

Sumner MD, Wotherspoon SJ, Hindell MA (2009) Bayesian estimation of animal movement from archival and satellite tags. PLoS ONE 4:e7324

Thiebot JB, Pinaud D (2010) Quantitative method to estimate species habitat use from light-based geolocation data. Endang Species Res 10:341-353

$>$ Tobin PC (2004) Estimation of the spatial autocorrelation function: consequences of sampling dynamic populations in space and time. Ecography 27:767-775

Tomczak M, Godfrey J (2003) Regional oceanography: an introduction. Daya, New Delhi

Van den Berg AB, Smeenk C, Bosman CAW, Haasa BJM, Van der Niet AM, Cadée GC (1991) Barau's Petrel Pterodroma baraui, Jouanin's Petrel Bulweria fallax and other seabirds in the northern Indian Ocean in June-July 1984 and 1985. Ardea 79:1-14

van Marle J, Voous K (1988) The birds of Sumatra: an annotated check-list. Check-list no 10, British Ornithologists' Union, Petersborough

Watanuki Y (1986) Moonlight avoidance behavior in Leach's storm-petrels as a defense against Slaty-backed gulls. Auk 103:14-22

> Waugh S, Weimerskirch H (2003) Environmental heterogeneity and the evolution of foraging behaviour in long ranging greater albatrosses. Oikos 103:374-384

Weimerskirch H, Wilson R, Lys P (1997) Activity pattern of foraging in the wandering albatross: a marine predator with two modes of prey searching. Mar Ecol Prog Ser 151: $245-254$

Weimerskirch H, Le Corre M, Marsac F, Barbraud C, Tostain O, Chastel O (2006) Postbreeding movements of frigatebirds tracked with satellite telemetry. Condor 108: 220-225

Wiggert JD, Hood RR, Banse K, Kindle JC (2005) Monsoondriven biogeochemical processes in the Arabian Sea. Prog Oceanogr 65:176-213.

> Wiggert JD, Murtugudde R, Christian JR (2006) Annual ecosystem variability in the tropical Indian Ocean: results of a coupled bio-physical ocean general circulation model. Deep-Sea Res II 53:644-676

Submitted: July 19, 2010; Accepted: December 1, 2010

Proofs received from author(s): February 3, 2011 